\title{
Influence of different temperature-salinity combinations on the oxygen consumption in the fresh water fish Etroplus maculatus (Teleostei)
}

\author{
Vipparti Parvatheswararao \\ Department of Zoology, Sri Venkateswara University, \\ Tirupati, India
}

KURZFASSUNG: Einfluß verschiedener Temperatur-Salzgehaltskombinationen auf den Sauerstoffverbrauch des Süßwasserfisches Etroplus maculatus (Teleostei). Der Einfluß verschiedener Temperatur-Salzgehaltskombinationen $\left(25^{\circ}, 30^{\circ}\right.$ und $35^{\circ} \mathrm{C}$; Süßwasser, $9,7 \%$, 19,4\% und $32,4 \%$ S) auf die Quantität des verbrauchten Sauerstoffs wurde für verschieden große Fische ermittelt, und zwar unmittelbar nach deren Überführung in das Versuchsmedium (Einzelheiten siehe unter "Material and Methods"). Temperaturerhöhung führt zu erhöhtem Sauerstoffverbrauch; das Ausmaß dieser Erhöhung ist eine Funktion des Salzgehaltes und außerdem der Körpergröße. In den höheren Salinitäten führte Temperaturerhöhung zu einer Depression des Sauerstoff verbrauchs bei den kleineren Individuen, aber zu einer verstärkten Erhöhung bei den größeren. In ähnlicher Weise wurden auch die Wirkungen des Salzgehaltsfaktors durch die Temperatur modifiziert. Die kleineren Individuen $(3 \mathrm{mg}$ ) zeigten den höchsten Sauerstoffverbrauch in den Kombinationen hohe Temperaturen/niedrige Salzgehalte; bei den größeren Individuen $(8 \mathrm{mg})$ dagegen erreichte der Sauerstoff verbrauch Maximalwerte in den Kombinationen hohe Temperaturen/hohe Salzgehalte. Möglidherweise besitzen kleine und große Individuen von E. maculatus unterschiedliche osmoregulatorische Fähigkeiten.

\section{INTRODUCTION}

It is now well established that the combined effects of temperature and salinity on metabolism and activity of animals may be altogether different from those of any one of these factors studied separately and, furthermore, that the effects of temperature and salinity on the metabolism and activity of animals are interdependent (KNNNE 1956, 1963, 1964, Prosser \& Brown 1961). Similar relationships have been shown to exist between other environmental factors as well. Hence, a bi-, tri- or polyfactorial analysis of physiological processes of poikilotherms is becoming increasingly preferred over the monofactorial approach. This development will lead to the production of data which are more suitable to be used for ecological considerations.

However, the number of bi-, tri- or polyfactorial analyses is still very limited. Most of the pertinent contributions have been written by KINNE and his associates (KInNe 1956, 1958, 1963, 1964, Kinne \& Kinne 1962a, b, SWEet \& Kinne 1964); 
others have been published by Demnel (1960), Dehnel \& MCCaughran (1964) and Todo \& Dehnel (1960). These studies especially demonstrated the combined effects of temperature and salinity on a variety of biological phenomena, such as thermal resistance, survival limits, ionic and osmotic regulation, reproduction and developmental rates, metabolism and activity, feeding and growth, and even distribution and morphology of a number of poikilotherms - invertebrates as well as vertebrates. The optimal temperature-salinity combinations were shown to differ from species to species, and in the same species from one season to the other (DEHNEL 1960).

In all these studies the test animals were acclimated to different temperaturesalinity combinations. Salinity tolerance is known to be usually greater after prolonged gradual transfer into a new concentration than after a sudden transfer (GRESENS 1928, Kinne 1960, Ahuja 1964). Hence it was considered worthwhile to study the influence of abrupt changes of temperature-salinity combinations on the rates of metabolism. Practically no work of this nature has been done except that by RAMAMURTHY (1962) on a few invertebrates, such as the cattle leech Hirudinaria granulosa, the fresh water mussel Lamellidens marginalis, the apple snail Pila globosa and the crab Paratelpbusa bydrodromus. No such studies have been conducted on fishes. The present study was carried out therefore on a locally available fresh water fish Etroplus maculatus.

\section{MATERYAL AND METHODS}

Etroplus maculatus BlEexer of the family Chromides is a eurythermal and eurysaline fresh water teleost. All individuals tested in this study were collected from local fresh water ponds and stocked in laboratory aquaria for at least a week before being used for experimentation. Oxygen consumption was measured in individual fish, using the WINKLER iodometric method (WELSH \& SMITH 1960). Combinations of four salinities, namely, fresh water (normal medium), $9.7 \% \mathrm{~S}(30 \%$ sea water), $19.4 \% 0 \mathrm{~S}(60 \%$ sea water $)$ and $32.4 \% \mathrm{~S}(100 \%$ sea water $)$, and three temperatures, namely, $25^{\circ} \mathrm{C}, 30^{\circ} \mathrm{C}$ and $35^{\circ} \mathrm{C}$, were used. In each set of experiments measurements were made in one medium but at different temperatures, the transfer from one temperature level to the other being abrupt and in ascending order starting from $25^{\circ} \mathrm{C}$. In each test temperature the fish stayed for about one hour.

Oxygen consumption was measured in individual fish at different temperatures in fresh water on the first day, in $30 \%$ sea water on the second day, in $60 \%$ sea water on the third day and in $100 \%$ sea water on the fourth day. Between the successive days of measurements the fish were kept in fresh water, their normal medium. At the end of the series of measurments, the wet weight of individual fish was recorded. Since measurements for each fish extended over a period of four days, the fish were allowed to feed in the normal way.

The blood chloride content of the fish, acclimated to different salinities, was determined by the GALLENKAMP electrometric microtitration apparatus. The sea water used had a chlorinity of $18.26 \%$ and salinity of $32.37 \%$. During the period of these studies the water temperature in the maintenance aquaria varied between $23^{\circ} \mathrm{C}$ and $27^{\circ} \mathrm{C}$, and hence $25^{\circ} \mathrm{C}$ may be taken as the mean adaption temperature. 


\section{RESULTS}

\section{Effects of temperature in various media}

The amount of the oxygen consumption increased with temperature but along different patterns in the different test media; furthermore, the temperature effect was size dependent (Figs. 1 to 4 ; Table 3).

In fresh water (Fig. 1), increase in oxygen consumption upon transfer from $25^{\circ} \mathrm{C}$ (adaptation temperature) to $30^{\circ} \mathrm{C}$ was negligibly slight in the smaller fish, but quite marked in the larger ones ( 4 grams body weight and more). Upon subsequent transfer from $30^{\circ}$ to $35^{\circ} \mathrm{C}$ the increase, however, was greater in the smaller individuals than in the larger ones, which, perhaps, were metabolically heat depressed as reflected in their depressed oxygen consumption at this temperature.

Increase in oxygen consumption upon sudden transfer from $25^{\circ}$ to $30^{\circ} \mathrm{C}$ was much greater in smaller fish in 30\% sea water (Fig. 2) than in fresh water at the same temperature. There were no indications of metabolic heat depression in the larger fish subsequent to transfer to $35^{\circ} \mathrm{C}$.

In $60 \%$ sea water (Fig. 3) oxygen consumption increased over the entire size range of the fish tested when the temperature was raised suddenly from $25^{\circ}$ to $30^{\circ} \mathrm{C}$. At $35^{\circ} \mathrm{C}$, however, there was considerable depression in the oxygen consumption of smaller fish.

In $100 \%$ sea water (Fig. 4) this metabolic depression commences already at $30^{\circ} \mathrm{C}$ and persists on to $35^{\circ} \mathrm{C}$ (Figs. 8, 9). Consequently, smaller fish $(3 \mathrm{gm})$ have negative $\mathrm{Q}_{10}$ values in the $30^{\circ}$ to $35^{\circ} \mathrm{C}$ range in $60 \%$ sea water and in the $25^{\circ}$ to $30^{\circ} \mathrm{C}$ range in $100 \%$ sea water (Table 1). The increased weight specific oxygen consumption at $35^{\circ} \mathrm{C}$

Table 1

Q10 values of oxygen consumption in the fish Etroplus maculatus as a function of body size (weight), temperature and salinity. S.W.: sea water

\begin{tabular}{|c|c|c|c|c|c|c|c|c|}
\hline \multirow{2}{*}{$\begin{array}{l}\text { Wt. of } \\
\text { fish } \\
\text { (gm) }\end{array}$} & \multicolumn{8}{|c|}{$\mathrm{Q}_{10}$} \\
\hline & $\begin{array}{r}\text { Fresh } \\
25^{0 \rightarrow 300^{\circ} \mathrm{C}}\end{array}$ & $\begin{array}{l}\text { water } \\
300 \rightarrow 35^{\circ} \mathrm{C}\end{array}$ & $\begin{array}{r}30 \% \\
250 \rightarrow 300 \mathrm{C}\end{array}$ & $\begin{array}{l}\text { S.W. } \\
300 \rightarrow 35^{\circ} \mathrm{C}\end{array}$ & $\begin{array}{r}60 \% \\
250 \rightarrow 300 \mathrm{C}\end{array}$ & $\begin{array}{l}\text { S.W. } \\
300 \rightarrow 35^{\circ} \mathrm{C}\end{array}$ & $\begin{array}{r}100 \% \\
250 \rightarrow 300 \mathrm{C}\end{array}$ & $\begin{array}{l}\text { S.W. } \\
30^{0} \rightarrow 35^{\circ} \mathrm{C}\end{array}$ \\
\hline 3 & 1.15 & 2.72 & 1.70 & 1.86 & 1.52 & 0.76 & 0.43 & 2.24 \\
\hline 8 & 1.90 & 1.47 & 1.76 & 1.84 & 1.97 & 2.37 & 1,83 & 2.15 \\
\hline
\end{tabular}

in $100 \%$ sea water may be due to the predominance of the stimulatory effect of increased temperature over the depressive effect of the increased salinity. This perhaps explains the high $\mathrm{Q}_{10}$ value for the $3 \mathrm{gm}$ fish in the $30^{\circ}$ to $35^{\circ} \mathrm{C}$ range. Except for these instances of metabolic depression at high temperature and high salinity, the weight specific oxygen consumption increased with increased temperature (Fig. 8). Larger fish $(8 \mathrm{gm})$ did not suffer any metabolic depression in any medium except for slight indications of it in fresh water and $30 \%$ sea water at $35^{\circ} \mathrm{C}$ (Fig. 9). 

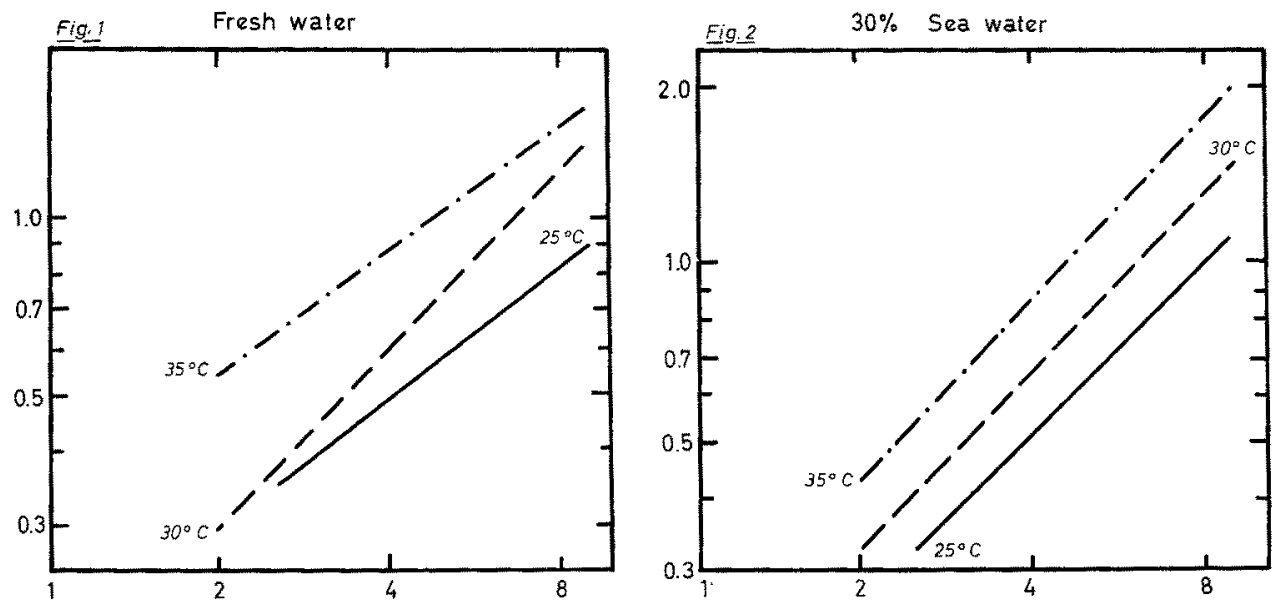

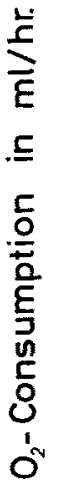
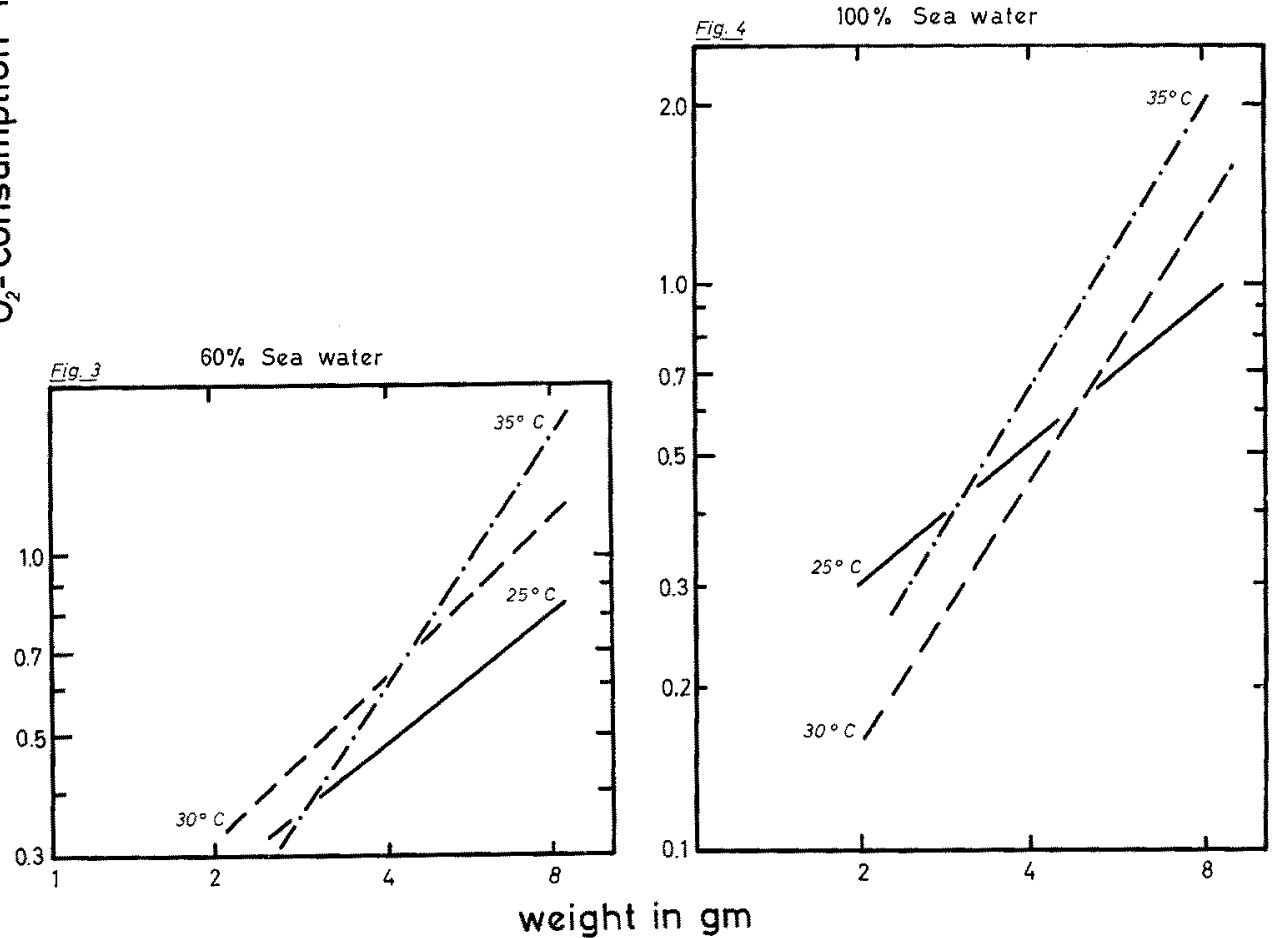

Figures 1, 2, 3 and 4: Influence of salinity on the temperature dependence of the size metabolism relation in the fish Etroplus maculatus. Oxygen consumption $(\mathrm{ml} / \mathrm{hr})$ was measured in individual fish immediately upon abrupt transfer from one constant temperature level to the next higher one in each test medium. The curves are statistically fitted by the method of least squares and plotted on a comparative basis on a double logarithmic grid. Individual points are omitted for clarity. 


\section{Effects of salinity at various temperatures}

Changes in the salinity of the medium affected the oxygen consumption of the fish in various ways (Figs. 5 to 7 and 10 to 12$)$. At the adaptation temperature $\left(25^{\circ} \mathrm{C}\right)$ oxygen consumption was minimal in $60 \%$ sea water; it was maximal in $100 \%$ sea water and quite high in fresh water, particularly in the $3 \mathrm{gm}$ fish. These results are in accord with the blood-medium chloride gradient, which is maximal in fresh water and $100 \%$ sea water, though in opposite directions, and minimal in $60 \%$ sea water (Table 2). It can be seen that at the adaptation temperature $\left(25^{\circ} \mathrm{C}\right)$, irrespective of the

Table 2

Blood-medium chloride gradient in Etroplus maculatus in heterosmotic media. All fish were kept in each test medium for seven days. Blood from several fish (small and large) was pooled up for the estimations. S.W.: sea water

\begin{tabular}{|lcccc|}
\hline Medium: & Fresh water & $30 \%$ S.W. & $60 \%$ S.W. & $100 \%$ S.W. \\
\hline $\begin{array}{l}\text { Chloride: } \\
\text { gradient: } \\
\text { mM/1 }\end{array}$ & +280 & +130 & -20 & -220 \\
\hline
\end{tabular}

salinity, the $3 \mathrm{gm}$ fish had higher rates of oxygen consumption than the $8 \mathrm{gm}$ ones. This was not so at the higher temperatures $\left(30^{\circ}, 35^{\circ} \mathrm{C}\right)$, where increased salinity of the medium appears to have depressed the oxygen consumption of the smaller fish and enhanced that of the larger ones (Figs. 7, 10 to 12). High temperature/high salinity combinations tend to reduce the oxygen consumption in the $3 \mathrm{gm}$ fish and increase it in the $8 \mathrm{gm}$ ones. The more concentrated the medium, the greater was the influence of

Table 3

Regression coefficient (b) of the size metabolism relation in Etroplus maculatus as a function of salinity of the medium at different temperatures. F.W.: fresh water; S.W.: sea water; S.E. est.: Standard error of estimate

\begin{tabular}{|c|c|c|c|c|}
\hline & F.W. & $30 \% \mathrm{~S} . \mathrm{W}$. & $60 \%$ S.W. & $100 \%$ S.W. \\
\hline \multicolumn{5}{|l|}{$25^{0} \mathrm{C}:$} \\
\hline$b$ & 0.750 & 0.978 & 0.773 & 0.811 \\
\hline S.E. est. & 0.1122 & 0.3431 & 0.2623 & 0.2560 \\
\hline "t"t" & 3.7870 & 2.1283 & 1.6721 & 1.7947 \\
\hline Significance & $1 \%$ & $5 \%$ & nil & nil \\
\hline \multicolumn{5}{|l|}{$30^{\circ} \mathrm{C}:$} \\
\hline$b$ & 1.019 & 1.014 & 0.895 & 1.519 \\
\hline S.E. est. & 0.1672 & 0.1872 & 0.1441 & 0.1948 \\
\hline " $t$ " & 4.4370 & 4.0435 & 4.5193 & 5.6632 \\
\hline Significance & $1 \%$ & $1 \%$ & $1 \%$ & $1 \%$ \\
\hline \multicolumn{5}{|l|}{$35^{\circ} \mathrm{C}:$} \\
\hline$b$ & 0.722 & 1.009 & 1.405 & 1.543 \\
\hline S.E. est. & 0.1454 & 0.1586 & 0.1328 & 0.2287 \\
\hline " $\mathrm{t} "$ & 3.5118 & 4.4971 & 5.2153 & 4.5976 \\
\hline Significance & $1 \%$ & $1 \%$ & $1 \%$ & $1 \%$ \\
\hline
\end{tabular}


Oxygen consumption in a fish

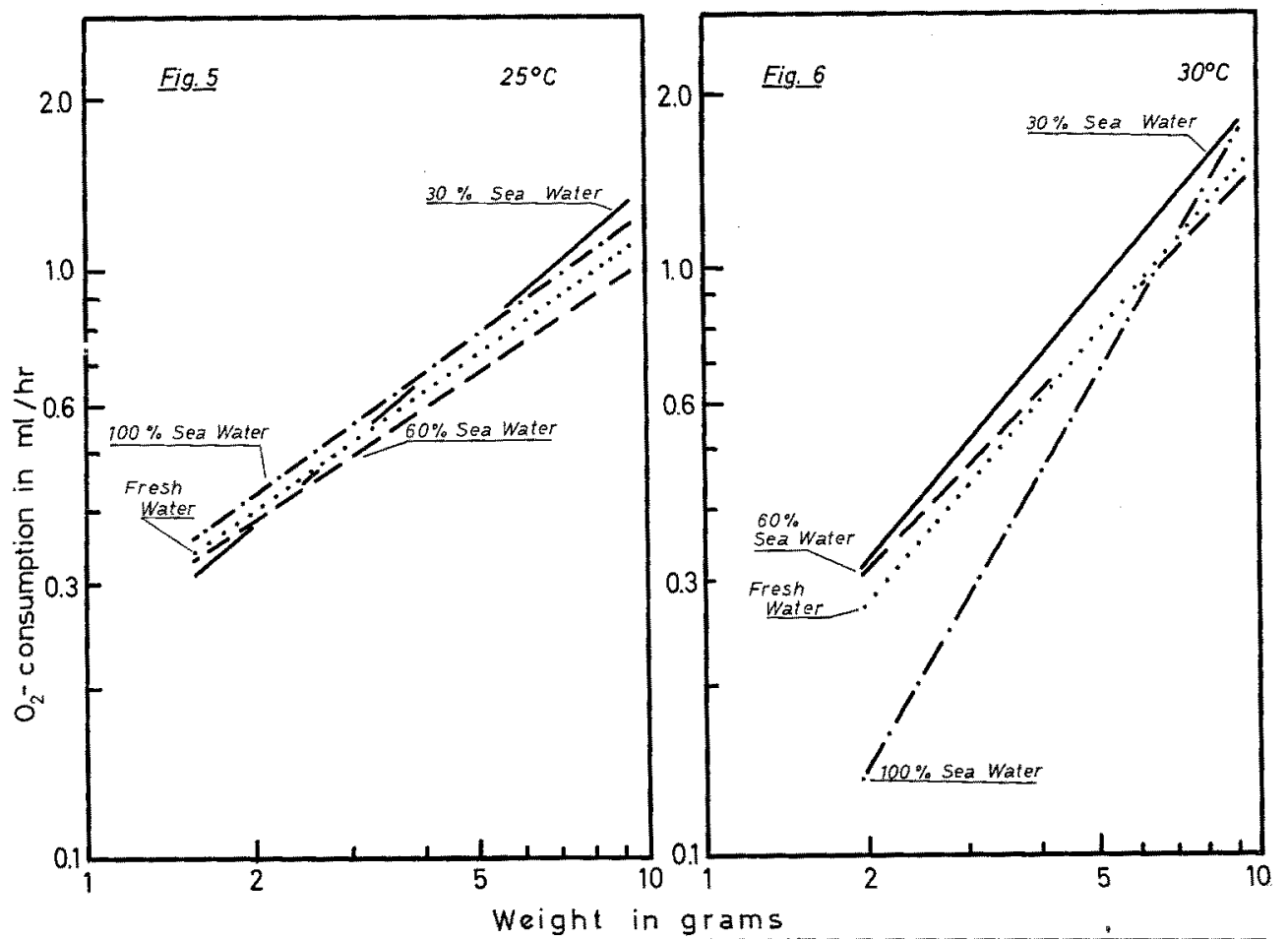

Figures 5, 6 and 7: Influence of temperature on the dependence of the size metabolism relation in the fish Etroplus maculatus. The curves of Figures 1 to 4 have been replotted on a comparative basis on a double logarithmic grid. S. W.: sea water; F. W.: fresh water.

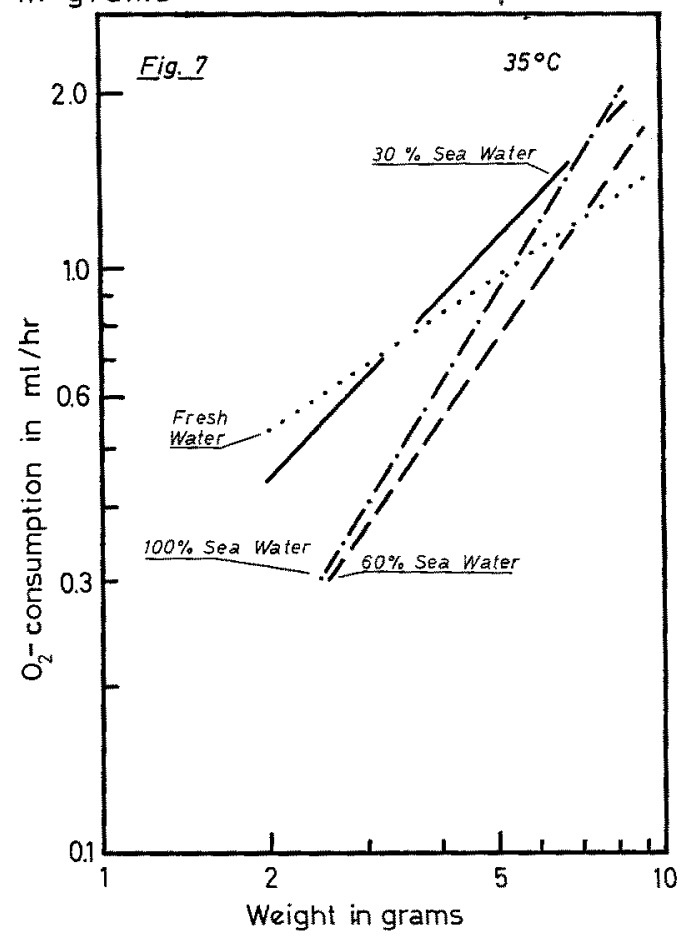


increased temperature on the oxygen consumption, though the effects are in opposite directions in the smaller versus larger fish. Accordingly, in the $8 \mathrm{gm}$ fish the $\mathrm{Q}_{10}$ increased in the $30^{\circ}$ to $35^{\circ} \mathrm{C}$ range with increasing salinity of the medium, while the opposite was true for the $3 \mathrm{gm}$ fish (Table 1). The high $\mathrm{Q}_{10}$ value in the $3 \mathrm{gm}$ fish in the $30^{\circ}$ to $35^{\circ} \mathrm{C}$ range in $100 \%$ sea water was apparently an exaggerated effect of the acute metabolic depression, suffered by the fish in this medium at $30^{\circ} \mathrm{C}$.

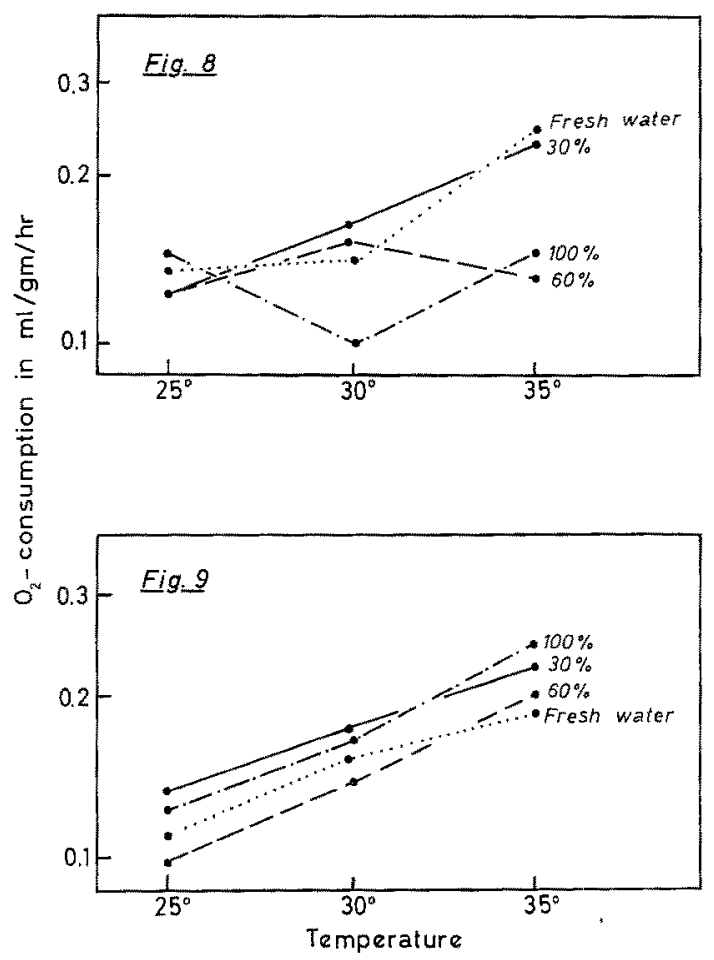

Figures 8 and 9: Weight specific oxygen consumption in Etroplus maculatus of $3 \mathrm{gm}$ (Fig. 8) and $8 \mathrm{gm}$ (Fig. 9) weights as a function of temperature in different media plotted on a semilog scale. The points are calculated from the corresponding size-metabolism curves of Figures 1 to 4. S.W.: sea water; F.W.: fresh water.

\section{$Q_{10}$ in relation to temperature and salinity}

The $Q_{10}$ values increased with increasing temperature in all salinities except in $60 \%$ sea water, where it decreased (Table 1). This increase or decrease was size dependent, being more marked in the $3 \mathrm{gm}$ fish than in the $8 \mathrm{gm}$ ones. This is apparently due to the acute metabolic depression suffered by the $3 \mathrm{gm}$ fish at $35^{\circ} \mathrm{C}$ in $60 \%$ sea water and at $30^{\circ} \mathrm{C}$ in $100 \%$ sea water.

The $Q_{10}$ values did not show any definite trend with the salinity of the medium. In the smaller fish, as in the $3 \mathrm{gm}$ ones, $\mathrm{Q}_{10}$ values initially increased in the $25^{\circ}$ to $30^{\circ} \mathrm{C}$ range on transfer to $30 \%$ sea water and thereafter decreased with the further 
increase in the salinity of the medium. This suggests that in the smaller fish metabolic depression commences with increased salinity and temperature of the medium. On the other hand, in the $8 \mathrm{gm}$ fish at the lower temperature range $\left(25^{\circ}\right.$ to $\left.30^{\circ} \mathrm{C}\right)$, there was no systematic trend in the $\mathrm{Q}_{10}$ values with increased salinity of the medium. $\mathrm{Q}_{10}$ values in the $30^{\circ}$ to $35^{\circ} \mathrm{C}$ range have already been discussed. In general, $Q_{10}$ values are higher at the higher temperature and in more saline media in all fish tested, small as well as large ones.

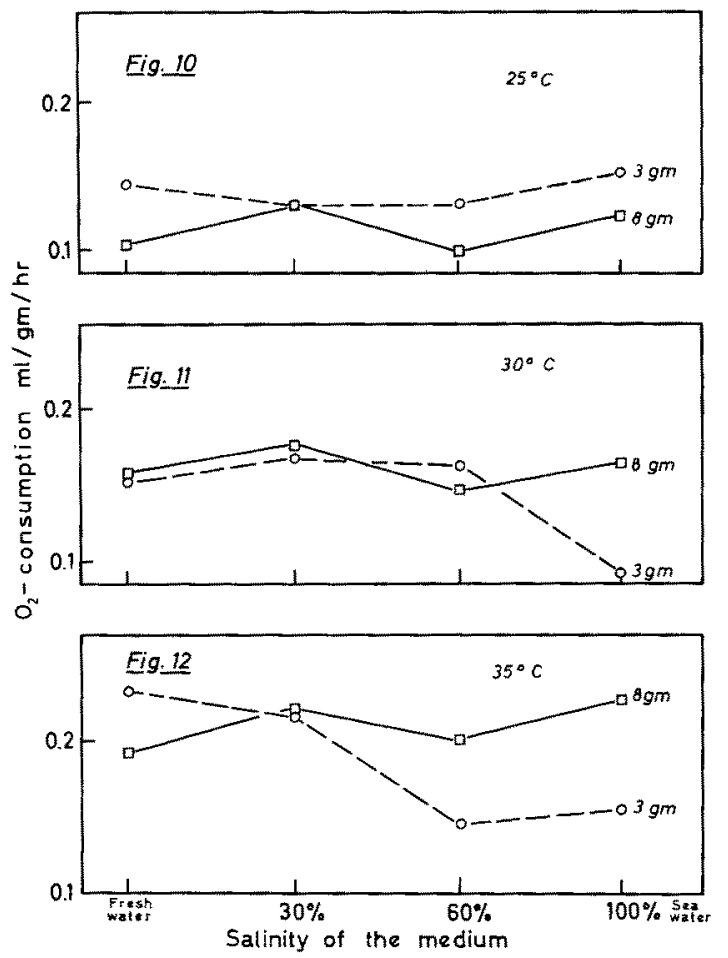

Figures 10, 11 and 12: Weight specific oxygen consumption in Etroplus maculatus of 3 gm and $8 \mathrm{gm}$ weights respectively as a function of salinity at $25^{\circ} \mathrm{C}$ (Fig. 10), 30 $0^{\circ} \mathrm{C}$ (Fig. 11) and $35^{\circ} \mathrm{C}$ (Fig. 12) plotted on a semilog scale. The points used in Figures 8 and 9 have been replotted. S.W.: sea water; F.W.: fresh water.

\section{DISCUSSION}

In any type of ecosystem organisms respond physiologically to the interplay of the environmental factors, such as temperature and salinity, rather than to any one factor individually. In several marine organisms lowering of salinity resulted in increased oxygen consumption (SChLIEPER 1929, Flemister \& Flemister 1951, Kinne 1952, 1964, Lofts 1956, Gross 1957, Pampapathi Rao 1958b, MadanMohanrao \& Pampapathi Rao 1962). This was ascribed (1) to greater osmotic work required consequent to the greater osmotic gradient between the body fluids and the external medium and (2) to increased hydration of tissues. But what happens metabol- 
ically in marine animals exposed to lowered salinities need not necessarily be repeated though in the opposite direction - in fresh water forms exposed to media of increased salinity, since these two groups are quite different from each other physiologically. This was clearly demonstrated in fresh water and marine populations of the prawn Palaemonetes varians (LoFTs 1956), in the marine and brackish water populations of the prawn Metapenaets monoceros (PAMpapathi RaO 1958b) and also in the brackish water and marine crustaceans Sesarma plicatum and Lepas anserifera (MADANMOHANRAO \& Pampapathi Rao 1962).

Generally the responses of organisms to sudden transfer into new media are characterised by a considerable degree of variation. Nevertheless a few trends are obvious. Oxygen consumption of the fish Etroplus maculatus was influenced by changes in salinity; the degree of this influence was found to be size dependent as can be seen from the regression coefficients (b) of the size-metabolism curves, particularly at the higher temperatures (Figs. 5 to 7; Table 3). Except at the higher temperatures, the $b$ values did not show a definite trend relative to the salinity levels employed. The same situation was also reported for the prawn, Metapenaeus monoceros (PAMpapathi RaO 1958b) and for Etroplus maculatus by SAROJINIDEvr (1960). In the present study, the level of oxygen consumption in the different test salinities at the adaptation temperature of $25^{\circ} \mathrm{C}$ appears to be correlated to the chloride gradient between blood and external medium. In fresh water and $100 \%$ sea water, where the blood-medium chloride gradient was maximal, oxygen consumption too was maximal, and in $60 \%$ sea water, where the blood-medium chloride gradient was minimal, oxygen consumption was minimal. Minimal oxygen consumption in media with minimal osmotic gradient was reported for a number of crustaceans, such as Ocypode albicans (FLEMISTER \& Flemister 1951), Metapenaeus monoceros (Pampapathr Rao 1958b), Paratelpbusa bydrodromus (Ramamurthy 1962), Sesarma plicatum (Pampapathi Rao \& MadanMOHANRAO 1963) and for the fish, Etroplus maculatus (SAROJINIDEvi 1960).

All higher fishes are more or less homoeosmotic (BLACK 1957). Probably E. maculatus too is an active and efficient osmotic regulator. This assumption appears justified in view of the facts that (1) this fish could tolerate transfer in to undiluted and even hyperconcentrated sea water without any apparent deleterious effects (PAMPAPATHI RAO 1958a) and, as indicated in the present experiments, (2) the differences in the levels of oxygen consumption in the different test media were but slight (Fig. 5). This eurysalinity may perhaps be due to the high blood chloride content and the high blood-tissue chloride gradient. It was shown in a few crustaceans that a correlation existed between the blood chloride content and the salinity tolerance of the animal (Beadle \& Cragg 1940, Duval 1925, Ramamurthy 1962). It was also shown that a fresh water fish Cirrhina reba with a relatively low chloride content was incapable of surviving highly saline media (Selvarajan 1962). But then, in the present case, despite active osmoregulation, there was no significant increase in oxygen consumption to meet the extra energy demands for doing the osmotic work against the increased osmotic gradient. Three possibilities might explain these results: (1) the mass of tissue doing osmotic work is so small compared to the total mass of body tissues that changes in their metabolic rate may be masked; (2) the energy required for the maintenance of the osmotic gradient is so small that there may not be much increase 
in oxygen consumption with increased osmotic stress (see also Peters 1935, Potts 1954, Dehnel 1962, Hickman 1962); (3) sudden transfer into new media introduces greater variability in activity and response pattern, which may overshadow smaller differences in energy balance.

It is obvious that the temperature response of the fish was modified by changes in the salinity of the medium and that this effect is size dependent (Figs. 1 to 4). Increased salinity, especially at the higher temperatures, appears to have had a marked effect on the smaller fish, which therefore suffered acute metabolic depression at $35^{\circ} \mathrm{C}$ in $60 \%$ sea water and at a lower temperature $\left(30^{\circ} \mathrm{C}\right)$ in $100 \%$ sea water. With increasing salt concentration of the medium, the metabolic depression became progressively more acute and set in at a relatively lower temperature. But a further raise in temperature to $35^{\circ} \mathrm{C}$ obliterated the metabolic depression suffered by the $3 \mathrm{gm}$ fish at $30^{\circ} \mathrm{C}$ in $100 \%$ sea water. Perhaps an increased thermal stress masks the effects of increased osmotic stress. On the whole, the high temperature/high salinity combination does not appear to suit the smaller fish. This is in agreement with earlier reports on several shrimps, such as Crangon crangon (Broekema 1941), Palaemonetes varians and Leander serratus (Panikkar 1940), Penaeus duorarum and Peaztecus (Williams 1960) and the fish, Salmo trutta (Gordon 1959), whose survival rates were highest at the low temperature/high salinity combination or vice versa (see also KINNE \& KINNE 1962, SwEET \& KINNE 1964, KinNe 1964).

Unlike in the smaller fish, no depressive effects of increased salinity were noticeable in the larger ones, where high salinity/high temperature combinations appear to be best suited, somewhat similar to the results obtained on the fish, Cyprinodon macularius, where optimum temperature for growth was found to decrease with age and increase with salinity (KINNE 1960). Actually the indications of metabolic depression, noticed in larger fish at $35^{\circ} \mathrm{C}$ in the fresh water medium, disappeared when the salinity of the medium was increased. This is clearly reflected in the $\mathrm{Q}_{10}$ values of the $8 \mathrm{gm}$ fish which increased with salinity in the $30^{\circ}$ to $35^{\circ} \mathrm{C}$ range. Perhaps, this is an instance of increased salinity increasing the heat resistance as suggested by KINNE (1956) and as reported by Ranade (1957) in Tigriopus fulvus and by Matutan (1962) in Tigriopus japonicus.

LOEB \& WASTENEYS (1912) showed that the fish, Fundulus beteroclitus, withstood osmotic stress better at a high temperature, provided it was acclimated to that temperature. Similar abilities of withstanding osmotic stress better at a high temperature are indicated in the present case as well but only in the larger fish. Possibly, as far as the larger fish are concerned, high salinity might have acted as a complimentary factor to high temperature, a fact reflected in the trend of the regression coefficients of the sizemetabolism curves in the different test media at $35^{\circ} \mathrm{C}$ (Fig. 7; Table 3). It appears thus that in Etroplus maculatus, increased salinity influences the temperature effect on metabolism; such an influence was, however, strictly size controlled. Though no conclusive evidence is available at present, it seems likely that osmoregulatory abilities are different in the smaller versus the larger individuals of Etroplus maculatus (PARVATHESWARARAO 1962). The reported size differences in the rise of metabolic rate in the starry flounder Platichtbys stellatus upon transfer to fresh water from more concentrated media (Hickman 1962) are in support of this hypothesis. 


\section{SUMMARY}

1. Oxygen consumption of Etroplus maculatus was measured immediately upon transfer into different temperature-salinity combinations. Four salinities (fresh water, $9.7 \%, 19.4 \%$ and $32.4 \%$ and three temperatures $\left(25^{\circ}, 30^{\circ}\right.$ and $35^{\circ} \mathrm{C}$ ) have been used in the combinations indicated.

2. The effects of temperature-salinity combinations on oxygen consumption were analysed on a size basis. In larger fish, temperature increase augments oxygen consumption in all test salinities. These changes are a function of the salinity, and, in addition, are size dependent. In the higher salinity levels, sudden temperature increase tends to result in relatively lower rates of oxygen consumption (compared to the rates obtained at $25^{\circ} \mathrm{C}$ ) in the smaller fish (depression), but in relatively higher rates in the larger ones (elevation).

3. Similarly, the effects of salinity on the oxygen consumption were modified by temperature. At higher temperatures, increased salinity depressed the oxygen consumption of the smaller fish and elevated that of the larger ones.

4. Smaller individuals exhibited the highest $\mathrm{O}_{2}$-consumption in combinations of high temperatures and low salinities, while the larger ones exhibited maximum $\mathrm{O}_{2}$-consumption in combinations of high temperatures and high salinities.

5. The possibility of the existence of differences in the osmoregulatory abilities between the smaller and larger individuals of Etroplus maculatus is suggested. But no conclusive evidence is available at present either in support of or against this hypothesis.

\section{ACKNOWLEDGEMENTS}

I would like to thank Dr. K. Pampapathi Rao, Professor of Zoology, Sri Venkateswara University, Tirupati, for his guidance in the course of this study and my colleagues, Messrs G. Bhaskara Rao and P. V. Ramamurthy, for helping me in the statistical analysis of the data. It is a pleasure to express my deep gratitude to Dr. O. KInne, Leading Director and Professor of the Biologische Anstalt Helgoland, for critically going through my manuscript and offering helpful suggestions.

\section{LITERATURE CITED}

Ahuja Surender, K., 1964. Salinity tolerance of Gambusia affinis. Indian J. exp. Biol. 2, $9-11$.

Beadle, L. C. \& Cragg, J. B., 1940. Studies on adaptation to salinity in Gammarus spp. 1. Regulation of blood and tissues and the problem of adaptation to fresh water. J. exp. Biol. 17, 153-163.

Black, V. S., 1957. In: Physiology of fishes. Ed. by M. E. Brown. Vol. 1. Acad. pr., New York, $447 \mathrm{pp}$.

Brokkema, M. M. M., 1941. Seasonal movements and the osmotic behaviour of the shrimp, Crangon crangon (L). Archs néerl. Zool. 6, 1-100.

DehNeL, P. A., 1960: Effect of temperature and salinity on the oxygen consumption of two intertidal crabs. Biol. Bull. mar. biol. Lab., Woods Hole 118, 215-249. 
- 1962. Aspects of osmoregulation in two species of intertidal crabs. Biol. Bull. mar. biol. Lab., Woods Hole 122, 208-227.

- \& McCaughran, D. A., 1964. Gill tissue respiration in two species of estuarine crabs. Comp. Biochem. Physiol. 13, 233-259.

Duvar, M., 1925. Recherches physico-chemiques et physiologiques sur le milieu interieur des animaux aquatiques. Modifications sous influence du milieu exterieur. Annls Inst. océanogr., Monaco 2, 232-407.

Flemister, L. J. \& Flemister, S. C., 1951. Chloride ion regulation and oxygen consumption in the crab, Ocypode albicans (Bosq). Biol. Bull. mar. biol. Lab., Woods Hole 101, 259-273.

Gordon, M. S., 1959. Ionic regulation in brown trout (Salmo trutta L.). J. exp. Biol. 36, 227-250.

- 1959. Osmotic and ionic regulation in Scottish brown trout and sea trout (Salmo trutta L.). J. exp. Biol. 36, 253-259.

Gresens, J., 1928. As cited by Kinne, 1964.

Gross, W. J., 1957a. An analysis of response to osmotic stress in selected decapod crustacea. Biol. Bull. mar. biol. Lab., Woods Hole 112, 43-62.

- 1957b. A behavioural mechanism for osmotic regulation in the semi terrestrial crab. Biol. Bull. mar. biol. Lab., Woods Hole 113, 268-273.

Hickman, C. P., 1962. Effect of salinity on the metabolic rate of gill and kidney of starry flounder, Platichthys stellatus. Am. Zool. 2, 130.

Kinne, O., 1952. Zur Biologie und Physiologie von Gammarus duebeni LILLJ. V. Untersuchungen über Blutkonzentration, Herzfrequenz und Atmung. Kieler Meeresforsch. 9, 145-150.

- 1956. Über Temperatur und Salzgehalt und ihre physiologisch-biologische Bedeutung. Biol. Zbl. 75, 314-327.

- 1958. Adaptations to salinity variations - Some facts and problems. In: Physiological adaptation. Ed. by C. L. Prosser, Am. Physiol. Soc., Wash., D. C., 185 pp.

- 1960. Growth, food intake and food conversion in a euryplastic fish exposed to different temperatures and salinities. Physiol. Zool. 33, 288-317.

- 1963. The effects of temperature and salinity on marine and brackish water animals. 1. Temperature. Oceanogr. mar. Biol. A. Rev. 1, 301-340.

- 1964. The effects of temperature and salinity on marine and brackish water animals. 2. Salinity and temperature salinity combinations. Oceanogr. mar. Biol. A. Rev. 2, 281-339.

- \& KINNE, E. M., 1962a. Effects of salinity and oxygen on developmental rates in a cyprinodont fish. Nature, Lond. 193, 1097-1098.

-, - 1962b. Rates of development in embryos of a cyprinodont fish exposed to different temperature-salinity-oxygen combinations. Can. J. Zool. 40, 231-253.

LoeB, $J$. \& W WATENEYs, $H$., 1912. On the adaptation of fish (Fundulus) to higher temperatures. J. exp. Zool. 12, 543.

LorTs, B., 1956. The effect of salinity change in the respiratory rate of the prawn, Palaemonetes varians (Leach). J. exp. Biol. 33, 730-736.

Madanmohanrao, G. \& Pampapathi RaO, K., 1962. Oxygen consumption in a brackish water crustacean, Sesarma plicatum (Latreille) and a marine crustacean, Lepas anserifera L. Crustaceana 4, 75-81.

MatUTAN, K., 1962. Studies on the temperature and salinity resistance of Tigriopus japonicus. 4. Heat resistance in relation to salinity of Tigriopus japonicus acclimated to dilute and concentrated sea waters. Seiro-Seitai 10,63-67.

PampapathI RaO, K., 1958a. Salinity tolerance of Etroplus maculatus (Bloch). Curr. Sci. 27, 99.

- 1958b. Oxygen consumption as function of size and salinity in Metapenaeus monoceros Fab. from marine and brackish water environments. J. exp. Biol. 35, 307-313.

- \& Madanmohanrao, G., 1963. Chloride regulation and its relation to oxygen consumption in the bradkish water crab, Sesarma plicatum (Latreille). Crustaceana 5, 188-192.

PanikKar, N. K., 1940. Influence of temperature on osmotic behaviour of some crustacea and its bearing upon problems of animal distribution. Nature, Lond. 146, 366-367. 
Parvatheswararao, V., 1962. Studies on the oxygen consumption in fresh water fish. (Doct. thesis submitted to Sri Venkateswara Univ.)

Peters, H., 1935. Uber den Einfluß des Salzgehaltes im Außenmedium auf den Bau und die Funktion der Exkretionsorgane dekapoder Crustacean (nach Untersuchungen an Potamobius fuviatilis und Homarus vulgaris). Z. Morph. Ökol. Tiere 30, 355-381.

PotTs, W. T. W., 1954. The energetics of osmoregulation in brackish water and fresh water animals. J. exp. Biol. 31, 618-630.

Prosser, C. L. \& Brown, Jr. F. A., 1961. Comparative animal physiology. 2nd ed. Saunders, Philadelphia, Pa., 688 pp.

Ramamurthy, R., 1962. Studies on the oxygen consumption of fresh water poikilotherms in relation to osmotic stress. (Doct. thesis submitted to Sri Venkateswara Univ.)

RaNADE, M. R., 1957. Observations on the resistance of Tigriopus fulvus (Fischer) to changes in temperature and salinity. J. mar. biol. Ass., $U, K, \mathbf{3 6}, 115-119$.

Sarojinrdevi, C., 1960. Studies on the effect of salinity on the oxygen consumption of Etroplus maculatus. (M. Phil. thesis submitted to Sri Venkateswara Univ.)

SCHXIEPER, C., 1929. Uber die Einwirkung niederer Salzkonzentrationen auf marine Organismen. Z. vergl. Physiol. 9, 478-514.

SeIvarajan, V. R., 1962. Chloride regulation in a fresh water fish, Cirrbina reba under heterosmotic conditions and high temperature. Proc. Indian. Acad. Sci. (B) 55, 91-98.

SweEt, J. G. \& KrnNe, O., 1964. The effects of various temperature-salinity combinations on the body form of newly hatched Cyprinodon macularius (Teleostei). Helgoländer wiss. Meeresunters. 2, 49-69.

TodD, M. E. \& DEFrned, P. A., 1960. The influence of temperature and salinity on heat tolerance in two grapsoid crabs, Hemigrapsus nudus and Hemigrapsus oregonensis. Biol. Bull. mar. biol. Lab., Woods Hole 118, 150-172.

WeLSH, J. H. \& SMTTH, R. I., 1960. Laboratory exercises in invertebrate physiology. Burgess, Minneapolis, Minn.

Williams, A. B., 1960. The influence of temperature on osmotic regulation in two species of estuarine shrimps (Penaeus). Biol. Bull. mar. biol. Lab., Woods Hole 119, 560-571. 